\title{
Europe United in Diversity-An Analogical Hermeneutics Perspective
}

\author{
PABLO CRISTÓBAL JIMÉNEZ LOBEIRA ${ }^{1}$ \\ Visiting Fellow, Australian National University, Centre for European \\ Studies \\ pablo.jimenez@anu.edu.au
}

\begin{abstract}
At a moment when a new crisis threatens Europe-a crisis including, among other factors, COVID-19, a faltering economy, immigration and Brexit-the European Union (EU) motto of 'Europe united in diversity' would appear progressively less attainable. This paper submits that the European ideal is still both desirable and possible through fostering of political unity at the constitutional (regime) level by using the notions of analogical state and analogical culture, and at the community level by enabling public sphere secularity and relational interculturalism. These concepts envisage the EU in a more flexible manner, in favour of policies enabling further European integration.
\end{abstract}

Keywords: analogical culture, analogical state, EU, public sphere secularity, relational interculturalism

On Tuesday 3 March 2020 Davide Sassoli, President of the European Parliament, made a statement following the European Commission's announcement of measures to address COVID-19. Less than two minutes long, Sassoli's statement nevertheless symbolised 'things old and new' in the history of European integration:

Not since the end of the Second World War have we faced such a dramatic crisis. Today the European Union is taking action... This situation is so serious that no European government could think of responding alone. The package of measures put forward by the European Commission today to fight COVID-19 goes in the right direction... The first priority is saving human lives. The other commitment is to protect jobs, businesses and the economy. To do this: enough with austerity. Countries are authorized to spend everything that is necessary to guarantee support for employees, self-employed workers, businesses, and banks... To save our countries, we must act together... Today the watchword for Europe is solidarity. No one will be left alone and no one will act alone. (European Parliament 2020).

Such words and their deep implications would have been unthinkable only a few years ago, even as recently as during the Greek crisis (Irwin 2015). Yet, they were not out of

\footnotetext{
${ }^{1}$ I would like to thank Dr Kasia Williams and participants of the 2020 ESAANZ conference, as well as anonymous reviewers, for insightful comments and suggestions to an earlier version of this paper.
} 
place. Not only did they correspond to the magnitude of the challenge posed by the new pandemic to Europe, but their historic reference to the catastrophe of the Second World War was accurate and legitimate, as that event provided the background for the beginning of European integration (Jiménez Lobeira 2014b:94-97). This realisation prompted discussion and even serious consideration of an economic recovery plan, 'Next Generation EU', a coordinated, EU-level investment stimulus supported by all EU members (Verwey et al. 2020). The result was 'a giant leap in fiscal integration' (Politico 2020a) which conferred on the Commission extraordinary powers to borrow up to $€ 750$ on the capital markets on behalf of the Union (Council of Europe 2020:3).

However, it is easier to talk about solidarity and unity than to bring them to practical outcomes. This article advances ways of visualising the EU fostering its cohesion in the face of the latest challenges Europe faces: COVID-19, a faltering economy, troubled migrant integration, and Brexit. The argument is organised into two sections. The first one considers the EU in its political form or 'constitution' (politeia). The second one regards its community of citizens (koinônia politikê). The common assumption running throughout both sections is that in order to stay together, the EU needs to envision itself in more flexible ways. The final part summarises this view and points to possible paths for further research derived from it. In terms of methodology, the concepts presented are set within a political theory approach in the sense aptly described by Dryzek et al. (2013) and following the outline sketched in Jiménez Lobeira (2010c). The methodology of analogical hermeneutics applied in this article to political analysis of the EU is elucidated in detail in Jiménez Lobeira (2015:6-19).

\section{The European Politeia}

Part of the difficulty in approaching any issue related to the EU is its political form, regime or 'constitution', what Aristotle referred to as politeia (Miller 2018). The problem becomes evident in the current circumstances: a 'European' response to the problems the EU faces is difficult because there is a difference between the EU polity and an ordinary state. As has been widely pointed out, the EU cannot be accurately described either as a state or as an international organisation: it constitutes a 'paradox' (Shaw and Wiener 2000). Since it is nearly impossible to categorically define what the EU is, some researchers have opted for indirect descriptions, by applying the medieval axiom 'action follows being' (Contreras Aguirre 2010) and thus deriving what the EU is from what it does (Ferrera \& Giuliani 2008:22). Thus, as explained in the next section, the EU can be better defined in analogical terms (Bickerton 2015:204-207), i.e. as 'a sort of state', or 'similar to a confederation', but without being one. When the EU is seen in analogical terms, though, some categories that have been widely used in European studies must be recalibrated, for instance the perceived 'democratic deficit' that implicitly-if inaccurately-assumes the EU to be a state, as Shaw \& Wiener have insightfully pointed out (2000:65).

\section{Analogical State}

The EU is not a state properly speaking, though it resembles one. In this sense, it could be called an 'analogical state,' meaning a polity that operates like a state in some ways but is different in others. To illustrate why, let us consider the apparent similarity of the EU's executive branch of government (the Commission) with that of, for instance, the United States. It soon becomes obvious that the presidents of the European Commission and the United States are quite different. Or think of the resemblance 
between the European Parliament and that of Canada. On close examination, their functions and roles in governance are highly contrasting. ${ }^{2}$

In order to analyse the EU polity's situation, origins and desirable future, I use the term 'suprastatism' rather than the more common 'supranationalism's. The reason is that the EU is not a state containing several national groups or 'nations' (such as Sweden, Latvia or Canada), but rather a polity joining a considerable number of states. My claim is that what has been called 'nationalism' is often, in reality, 'statism': the promotion of one state above some or all others. True, once unmasked in this way, statism sounds much less appealing. This distinction between nationalism and statism sheds light on why the EU should not aim at becoming a state, or even less 'a nation': it already is a plurinational stateless polity.

Statism led to European confrontation over the two World Wars. The concept of nation may have been used as a pretext, but wars were waged between states composed of several national groups. From the outset of the European integration project, Schuman, Monnet and the other founders, devised instruments to keep statism in check. Thus, the first brick in the structure of integration was a 'supranational' (i.e. suprastatal) authority to resolve potential disputes between France and Germany arising from the joint production of coal and steel. Soon Luxembourg, Italy, Netherlands, and Belgium joined the project.

Weiler (1998:27) considers the idea of Europe becoming a state (or a superstate) an irony since, from its beginnings, the European project (at the 'communities' stage) was aimed at keeping statism in check. Habermas (2001b) has in mind a federation when he reflects on the desirable political form for the EU. He describes it as 'a community of nation-states that itself assumes some qualities of a state'. However, 'federation' can mean either the union of several provinces or states, or the act of federating - to unite or cause to unite in a federal union. There are degrees of federation, yet not all of them imply the creation of a state or a superstate. Confederacies contain, in fact, a level of federation. Europe can federate without becoming a state in the process.

The EU is not a confederation of sovereign, autonomous states, nor is it a federal state with a strong central government. From an analogical hermeneutics perspective, the union's regime has the political form of a federal state as the main referent of the analogy, though it tends towards a confederate arrangement without arriving at it. Viewed in this light, aspects of EU governance such as the 'piecemeal', consensusseeking, and the consequently slow approach to restructuring, introducing reform and making decisions, which makes so many observers despair, needs revisiting. Mixed

\footnotetext{
${ }^{2}$ For this reason, the identity necessary for its cohesion does not need to be strong but analogical too (Jiménez Lobeira 2010a). Europeans do not have to opt for either their national region or country, and Europe: they can have both (Jiménez Lobeira 2014a).

3 The notion of stateless suprastatism originates in Schuman and Monnet (Burgess 2011) and is developed by Joseph Weiler (1999) and Rainer Bauböck (2007), although they use the term 'supranationalism'. Weiler's description of the community method and his principle of constitutional tolerance are invaluable in understanding suprastatism. I explain this idea at greater length in Jiménez Lobeira (2015:22-23), distinguishing between state and nation, and pointing out that the political entities which conform the EU are not 'nations' but rather states. It is telling that they are referred to not as 'member nations' but as 'member states'. The reason is that states and nations do not always coincide: different national groups may live in one state (e.g. Latvia, Spain or Finland) and a nation may spread among several states (e.g. Catalans in France, Andorra and Spain). Besides, nations may have cultural expressions and history but not necessarily a legal and political form ('regime') as do states.
} 
arrangements, consensus-based decisions and hybrid solutions befit this stateless polity. 4

Considering that 'tensions in defining national identities are an ever-present phenomenon because the immanent feature of every identity is its fluidity, understood as the constant need to (re)define itself' (Ładykowski 2018:105), European identity should be regarded as analogical, and therefore capable of embracing elements from different perspectives and assuming them in a more comprehensive view. There is space for the more plausible elements in every perspective to be contained in a synthetic concept of European identity as analogical (Jiménez Lobeira 2010b). If European identity is going to work as a link to keep the European polity together, it needs some substance, some definition and its distinction from 'national'-memberstate-identity.

\section{Analogical Culture}

The content for such a European identity, understood as the 'political culture of human rights' ${ }^{5}$ is to be found in the 'EU values' of human dignity, freedom, democracy, equality, the rule of law and human rights (European Commission 2020) that are notionally shared by Europeans in all member states. This shared political culture can provide a common frame of reference, a medium for communication, for the discussion of matters of public interest between citizens possessing contrasting cultural backgrounds. This 'analogical culture' ${ }^{6}$ is not as strong as member-state national cultures and commands only a limited appeal-one of assent.

This analogical culture implies human rights, democracy and the rule of law but does not necessarily equate to the growing body of EU positive law and charters. Rather, it encapsulates the foundational motivations at the heart of European integration. It may not be as well-known and accepted in other parts of the world, but by and large it already forms part of what Europe is today. It is implicit in the values that potential joining states must eventually adopt to show their real will to be part of the EU (Petrov 2018:59-60). However, this analogical culture cannot take the place of national cultures, which provide an existential background to member states' political identities. It should be viewed not as a competing, strong national culture, but as a weaker version, definable enough to constitute a European axiological common ground, yet vague enough to allow for differing nuances across member states. However, even if weaker than national political culture those 'EU values' need to take the form of a living political culture that can be called genuinely European and help foster the polity's unity. To this end, a simple assent is not enough: these values need to be more than a concept in order to appeal to citizens. And shared concept becomes an appealing idea when it is discussed, shaped and appropriated by citizens in the public sphere. The analysis of how this appropriation can take place requires us now

\footnotetext{
4 Ferrera \& Giuliani (2008) have proposed 'governance' as a key element to understand the working of the EU while leaving aside the ontological ('What is it?') and teleological ('Where is it going?'). The authors' pragmatic approach is useful, however here we cannot overlook the 'ontological' and 'teleological' aspects, since they affect the legitimacy for the European polity.

${ }^{5}$ As I have called in Jiménez Lobeira 2015:16-19

${ }^{6}$ Which contains the inspirations and 'the spirit' that motivated the creation of such great projects as the Council of Europe, the European Court of Human Rights and the European Communities, is highly relevant, as it illustrates how such analogical culture has already inspired the creation and working of highly significant institutions that already exist, and therefore it is well placed to support the cohesion of the European polity.
} 
to change our viewpoint from the EU as a regime or polity to the EU as a community of citizens.

\section{The European Koinônia Politikê}

The process of EU integration has created a perception within the community of citizens that they have progressively less power to influence decision-making both at the national and the European level (Schmidt 2015:219-223). The fact that a significant portion of the immigrants coming to Europe possesses a different-often strongly religious-background (Pew Research 2017) ${ }^{7}$, at times exaggerated by the media, has magnified this perception, resulting in an increasingly stressed public sphere and a more divided society. This tension increases when religion and secularism adopt more extreme forms, as in the case of Samuel Paty. ${ }^{8}$ The European public sphere is the place where generic values that have an in principle assent from European citizens can take concrete form and turn into living convictions shared by the political community. However, for this shared political culture to be formed, the cultural backgrounds of the participants must be acknowledged, respected and appreciated.

\section{Public Sphere Secularity}

The public sphere is not limited to the announcement of initiatives that affect the political community. It enables the free expression and discussion of ideas - even controversial ones. Among others, Longo (2019) has pointed out the importance of a public sphere that bridges the gap between the national and European realms to strengthen European political identity. He sees in the European Citizens Initiative (ECI) a concrete way to achieving it. One interesting example of ECI is 'Voters Without Borders-full political rights for EU citizens', seeking to gain the ability for EU citizens to vote in their country of residence instead of their country of origin. Organisers claim that by 2020, over 17 million EU citizens live or work in a member state different from their country of origin (Voters Without Borders 2020).

Secularity, or the creation of an open frame for discussion of different worldviews, ${ }^{9}$ is an essential feature of the public sphere. Secularism, by contrast, is only one among several worldviews-including religious ones-deserving the respect that all of them deserve. None of those worldviews should monopolise the European public sphere. A secular public sphere is an ideal stage for political discussion and for the building of social cohesion and civic identity. When a worldview is allowed to dominate the public sphere, citizens and residents holding different worldviews tend to feel alienated and find it more difficult to integrate.

\footnotetext{
${ }^{7}$ According to this study, the Muslim population in Europe is expected to grow, under a medium migration scenario, from 19.5 million (or $3.8 \%$ of the total population) in 2010 to 57.9 million (11.2\%) in 2050 . The EU member state with the highest Muslim population is France (which provides a good context for the Paty case), followed closely by Germany and Italy.

${ }^{8}$ A French middle school teacher beheaded on 16 October 2020 by an immigrant claiming to defend respect for the Muslim religion (Savarit-Lebrère 2020). Public discussion pitting secularism in the form of French laïcité against Islam ensued for months.

${ }_{9}^{9}$ In a previous analysis on the public sphere (Jiménez Lobeira 2014a:389-393), I have merged Casanova's 'secularism as statecraft', Taylor's 'open immanent frame' and Habermas's secular stage, in the notion of 'secularity'. Further, I have synthesised in 'secularism' what for Casanova is 'secularism as ideology', for Taylor the 'closed immanent frame' and for Habermas 'secularism as ideology'. The distinction between secularity and secularism is crucial, since the former denominates a neutral-or at least open-frame for discussion of different worldviews, religious or not, whereas the latter is a non-religious worldview (French laïcité might sometimes fall in this category; see Casanova 2014, and for a recent example, Deutsche Welle 2020).
} 
Habermas (2010), who has engaged in serious reflection on the revival of religion in a post-secular age, advocates such a secular public sphere (Bohman \& Rehg 2017). Given that Europe stands for some non-negotiable political values such as democracy, the rule of law and human rights, all with a clear cultural and historical background, the secularity of its public sphere cannot mean 'pure' neutrality devoid of any cultural traits. It can, however, aspire to be an open frame, which, even if imperfectly, accommodates the varied worldviews that members of the complex European political community hold.

Yet, even if the goal of secularity were met, the exchange of ideas in the public sphere would require that European citizens achieved a set of common attitudes through their day-to-day interaction. This exercise, which I term relational interculturalism, would generate integration and social cohesion.

\section{Relational Interculturalism}

Relational interculturalism sits between monoculturalism-the unqualified cultural assimilation of immigrants-and the kind of multiculturalism that tends to create parallel societies living in one polity. It proposes a way of interaction appreciative of different cultural backgrounds without renouncing to also spell out and appreciate the culture of the receiving population.

The notion of relational interculturalism is closely related to that of citizenship. The idea that the EU is a sui generis polity, or that its citizens are not a demos but a group of demoi is not new (Nicolaïdis 2004). ${ }^{10}$ Since the EU is a 'mixed-commonwealth'11 but not a state, understanding of its particular kind of citizenship becomes clearer with the aid of analogical hermeneutics. This tool enables us to envisage a polity resembling a federal state yet different in that EU citizenship hinges on the member state without either opposing or simply replicating it. In other words, being an EU citizen is not equivalent to, yet not entirely different from being an Austrian citizen: it is similar and compatible to a certain degree (Jiménez Lobeira 2012).

Any human organisation will have at its core certain values grounded in cultural underpinnings. Even those regimes that consider themselves 'value-free' possess a certain political culture with implied values and moral assumptions in their inner structure. ${ }^{12}$ A polity must reflect on and spell out these core values, and determine how much it is prepared to modify them when new members join the political community. This discussion affects the political culture of the polity as a whole as well as the interaction between its citizens, especially when they have contrasting-and potentially conflicting-cultural backgrounds. Cultural backgrounds are crucial because culture is essential to identity. An example is the ongoing discussion about the compatibility of Sharia Law within the European legal framework (Kalampakou 2019). A neutral, or at least agnostic, open European public sphere, acknowledges the value that religion has for a significant number of current or future citizens and sets an accommodating climate for interaction between them. This interaction would include not only transactional matters but also an appreciation of worldviews held dear by them. ${ }^{13}$

\footnotetext{
${ }^{10}$ See also: Jiménez Lobeira (2010b; 2012).

${ }^{11}$ Another term to designate the EU's hybrid regime, first coined by Neil McCormack (Jiménez Lobeira 2015:21).

${ }^{12}$ For a development of this idea see: Jiménez Lobeira (2011a).

13 This, of course, should be true also for Europeans holding a secularist worldview.
} 
In Europe, the substantive underlying culture that has produced and maintained its democracies springs from the Enlightenment, rooted in turn in 'Jerusalem, Athens and Rome' (Ratzinger 2019). This culture has found political expression in parties across Europe grouped under the Social Democracy and the Christian Democracy banners (Jiménez Lobeira 2014b). Having an underlying culture for the polity does not mean that it has to limit itself to that culture only, excluding other traditions. The challenge is to bring citizens of diverse cultural backgrounds to see themselves as part of the same polity (Longo 2019), including immigrant as well as host cultures. Relational interculturalism highlights the recognition of differences as the first step towards meaningful interaction in any civic community. ${ }^{14}$ Cultural exchange between people of different backgrounds is already complicated within an individual country. It becomes even more so in a stateless polity gathering several member states.

Relational exchange begins from the acknowledgement that 'the other' is neither 'another me' nor someone completely alien, a 'totally other'. Their difference is real, for sure, but not incommensurable. The concept of relational interculturalism combines Donati's relational sociology (Donati 2010) with Beuchot's analogical hermeneutics (Beuchot 2005a, 2005b). The 'another me' scenario mentioned above could describe the univocal idea of monoculturalism. The 'totally other' case would represent the opposite extreme, the equivocality or incommunicability of multiculturalism. Following previous analyses of paradigms for social cohesion (Jiménez Lobeira 2014b:105-108) and the nature of analogical hermeneutics (Beuchot 2005a:13-27, 2005b:77-88; Jiménez Lobeira 2015:6-11), relational interculturalism would sit between mono- and multiculturalism as an analogical position, where there is some similarity even in the midst of difference. The beheading of Samuel Paty in France in the name of Muslim values, the national discussion about this event (Macron 2020a, 2020b) and its international repercussions (Rettman 2020) illustrate the need for different approaches to the interaction of members of the political community to the approaches tried so far.

\section{That Old Little Subcontinent...}

Europe no doubt faces trying times. Immigration, COVID19 and its derived economic crisis; populism in member states and in the EU's main ally-the US; Brexit and the upcoming political transition in Europe's de facto leading country-Germany (Politico 2020b). These are all current significant challenges.

Brexit will bring important changes which the EU can, however, handle: the EU's population of 446 million is over 6 times the size of the UK's, with clear consequences in terms of economic importance and legal influence as explained by Gstöhl and Phinnemore (2020). The UK was one of the three most prominent EU member states. ${ }^{15}$ Now it will have to line up and share in the challenge that all EU neighbours interested in a privileged partnership face: 'they need to find an acceptable balance in the fundamental trade-off between the benefits resulting from broad participation in the internal market and the lack of real participation in EU decision-making' (Gstöhl \& Phinnemore 2020).

${ }^{14}$ See a more comprehensive explanation in Jiménez Lobeira (2015:28-30).

${ }^{15}$ Though not a founding member state and always a 'reluctant European' (Peet 2015). 
The value of the European project and its uniqueness become evident when we contrast Europe today with its chaos, resentment and poverty after WWII, and with the underwhelming outcomes of regional integration in other parts of the world. An illustration of its achievements is the transformative effect that enlargement has had in the societies of new member states. Enlargement has 'managed to trigger the expansion of the democratic ideal across the European continent' (Pérez-Solórzano Borragán 2015:239) even if with nuanced success.

There are signs that support for the European project may be growing, notwithstanding-or even thanks to-the rise of populist Euroscepticism in countries as crucial as Germany. As Turnbull-Dugarte (2020) has shown, the rise of Alternative für Deutschland has led the silent majority to double down on their European positions. In his view, 'the arrival of a threat to the pro-European consensus has served as something of a wake-up call for the previously complacent and permissive Eurocentrists who have now become Europhile and willing to "rally around" the EU.' If Turnbull-Dugarte (2020) is right, his finding could have implications beyond Germany: with 'the rise of a threat to EU membership' driving 'voters to be more supportive of EU integration and parties react along the same Europhile direction of travel.' Something similar might be happening in Poland, where the belligerent language of its government notwithstanding, support for Europe among the population not only has not decreased but is today higher than it was when the country joined the EU (Varga 2020).

Against the current background, this article has suggested that the European ideal is still both desirable and possible. Unity at the polity, regime level can be pursued through the notions of the analogical state-a suprastatal polity-and analogical culture-the sources that inspired today's EU Values. At the community, citizenry level, unity can be fostered through the enablement of public sphere secularity and relational interculturalism. These concepts envisage the EU in a more flexible manner, in favour of policies enabling further European integration.

At least five avenues to further research emerge from this piece. First, the idea of analogical unity implied in the concept of suprastatism calls for development. ${ }^{16}$ Since even advocates of a 'postnational EU' such as Habermas (2001a:98-103) ${ }^{17}$ still envisage it as a state, analogical unity and suprastatism must be expanded theoretically and tested empirically so that they can be alternatives to the vision of turning the EU into a state. ${ }^{18}$ Second, the relationship between political and economic unity and policy; concretely the consequences of a mixed-commonwealth regime for the economic architecture of the EU. ${ }^{19}$ Third, the comparison of integration between

\footnotetext{
${ }^{16}$ I have taken as possible illustrations of this kind of unity Weiler's descriptions of the original 'community system', suprastatism (which, as indicated above, he calls 'supranationalism') and his 'principle of constitutional tolerance' (summarised in Jiménez Lobeira 2014b and treated in detail in Weiler 1991:2410-2422 and 2005:184190).

${ }^{17}$ See also Jiménez Lobeira (2010b:34-36).

${ }^{18}$ Related to suprastatism is the expression of belonging to it revealed in EU citizenship and supported in the notion of analogical political identity (Jiménez Lobeira 2010b:31). One way of explaining this concept further is through what Beuchot (2004) calls the symbol in Analogical Hermeneutics. Another could be through the concept of citizenship as advanced by Linda Bosniak (2000, 2008, 2010 and 2011).

${ }^{19}$ I.e., The idea of how flexible and at the same time workable economic arrangements for the EU (Jiménez Lobeira 2014b) could work requires more elaboration. Similar deepening demand issues such as the 'fiscal union', agricultural subsidy arrangements, the role of the European Central Bank in the supervision of financial institutions, the setting of interest rates, and the discretionary use of monetary policy to fight unemployment, recession and panic attacks among investors. This area of discussion is now open as the economic effects of COVID-19 have prompted a search for EU-wide solutions (Zalan 2020). The matter is particularly relevant to
} 
Europe and other regions of the world, with the parameters I have used for political unity, political identity, political culture, and so on. ${ }^{20}$ Fourth, the main concepts of relational interculturalism need translation into concrete hypotheses for specific situations, tested empirically and, with that information, revisited theoretically too. ${ }^{21}$ Fifth, the exploration of religious elements incorporated in the Enlightenment's cultural background as a potential source of strategies for the integration of migrants with strong religious backgrounds. Could past experiences of interactions with Judaism and Christianity shed light in the search for more successful approaches to the encounter of European democracies with Islam today?

The future of Europe is by no means secured. Nevertheless, there can be a future-and a very desirable one-if Europeans continue to work towards it. Under certain conditions the EU could still expand beyond its present borders, to embrace even more member states (Wallace 2000) and foster in them prosperity, democracy and human rights, enhanced economic cooperation, research and educational exchange and intercultural enrichment. A united Europe can aspire to matter in the changing landscape of a globalised world as a normative power, a reliable trading partner and a promoter of multilateralism and international law.

\section{References}

Bauböck, Rainer (2007), 'Why European Citizenship? Normative Approaches to Supranational Union,' Theoretical Inquiries in Law, Vol. 8, No. 2. Accessed 7 May 2020, https://www7.tau.ac.il/ojs/index.php/til/article/view/642

Beuchot, Mauricio (2004), Hermenéutica, Analogía Y Símbolo. El Marqués, Querétaro: Herder.

Beuchot, Mauricio (2005a), En el camino de la hermenéutica analógica. San Esteban. Salamanca.

Beuchot, Mauricio (2005b), Interculturalidad y derechos humanos, UNAM - Siglo XXI. México.

some of the new member states which based their 'return to Europe' and became active members of the EU hoping to obtain clear economic gains in the long term, as Vaaks (2013:53-55) has shown for Estonia. 20 The success of European integration has yet to be matched by similar attempts in other regions of the world (Jiménez Lobeira 2015:15). Across the Mediterranean, the recently founded African Union and its predecessors have been laudable, though still not sufficient efforts. In the Asia Pacific, initiatives include ASEAN and more recently the Comprehensive and Progressive Agreement for Trans-Pacific Partnership (Chien-Huei Wu 2020). In the Western Hemisphere, Iberian America alone extends for circa twenty million sq km (more than five times the size of the EU) and encompasses twenty Spanish and Portuguese speaking countries with over 620 million inhabitants. It shares cultural, historic, economic, and political interests and has seen efforts of integration predating the foundation of the European Economic Community. Nevertheless, today it is still fragmented and split between a number of blocks including Mercosur and the Pacific Alliance. Pan-American initiatives such as the Organisation of American States have achieved some harmonisation goals (e.g. in the area of human rights) but rather modest levels of integration.

${ }^{21}$ In particular, how it relates to-and differs from-multiculturalism requires further elaboration though a start can be found in Jiménez Lobeira (2014b). Another path of research for relational interculturalism is its potential repercussions in the public sphere. Think for instance of the problem of translation of religious concepts to secular terms and vice versa (Jiménez Lobeira 2015:16). Finally, its connection with solidarity in the context of the economic and political crises in Europe: could relational interculturalism-and in what way-significantly influence the level of civic friendship, also translated into mutual help and care for those less economically fortunate present in the EU as a whole? 
Bickerton, Christopher (2015), 'From Nation-States to Member States: European Integration as State Transformation.' In: The Search for Europe. Contrasting Approaches. Madrid: BBVA, pp. 202-215. Viewed 16 July 2020, https://www.bbvaopenmind.com/en/books/the-search-for-europe-contraisingapproaches/

Bohman, James and Rehg, William (2017), "Jürgen Habermas", The Stanford Encyclopedia of Philosophy, Fall Edition, Edward N. Zalta (ed.). Viewed 28 October 2020, https://plato.stanford.edu/archives/fall2017/entries/habermas

Bosniak, Linda (2000). 'Citizenship Denationalized.' Indiana Journal of Global Legal Studies 7, no. 2: 447-509.

Bosniak, Linda (2008), The Citizen and the Alien: Dilemmas of Contemporary Membership. Princeton University Press.

Bosniak, Linda (2010), 'Persons and Citizens in Constitutional Thought.' International Journal of Constitutional Law 8, no. 1, January: 9-29.

Bosniak, Linda (2011), 'Citizenship in an Unequal World.' Perspectives on Politics 9, no. 03: 621-24.

Burgess, Michael (2011), 'Entering the Path of Transformation in Europe: The Federal Legacy of the Schuman Declaration.' French Politics, Culture \& Society 29, no. 2: 4-18. Accessed 6 May, 2020, www.jstor.org/stable/42843707

Casanova, José (2014), 'Secularización y laicidad en España y Europa Una perspectiva comparada', in: Reus SJ, Manuel (ed.) Secularización, laicidad y religión: Seminario con José Casanova. Universidad de Deusto.

Chien-Huei Wu (2020), ASEAN at the Crossroads: Trap and Track between CPTPP and RCEP, Journal of International Economic Law, Volume 23, Issue 1, March: 97-117, https://doi.org/10.1093/jiel/jgz032

Council of Europe (2020), 'Special meeting of the European Council (17, 18, 19, 20 and 21 July 2020) - Conclusions', 21 July 2020. Viewed 21 July 2020, https://www.consilium.europa.eu//media/45109/210720-euco-final-conclusions$\underline{\text { en.pdf }}$

Contreras Aguirre, Sebastián (2010), 'La normatividad de la naturaleza en Aristóteles y Santo Tomás. Physis y el derecho natural en la filosofía clásica.' Pensamiento, vol. 66, núm. 248, pp. 245-260. Viewed 17 July 2020, https://dialnet.unirioja.es/servlet/articulo?codigo $=3279110$

Deutsche Welle (2020), 'As France mourns slain teacher Samuel Paty, some question secular values', 24 October. Viewed 28 October 2020, https://www.dw.com/en/samuel-patyfrance-radical-islam-secularism/a-55383482

Donati, Pierpaolo (2010), Relational Sociology: A New Paradigm for the Social Sciences (Ontological Explorations), Routledge.

Dryzek, John S. (2013), Honig, Bonnie and Phillips, Anne. 'Overview of Political Theory', In: The Oxford Handbook of Political Science, Edited by Robert E. Goodin. published online September, https://doi:10.1093/oxfordhb/9780199604456.013.0002

European Commission (2020), 'The EU in Brief, Goals and Values in the EU'. Last updated 24 November 2020. Accessed 28 November 2020: https://europa.eu/europeanunion/about-eu/eu-in-brief_en\#goals-and-values-of-the-eu 
European Parliament (2020), 'Statement by David Sassoli, President of President of the European Parliament, following the announcement by the European Commission of measures to address COVID-19, 3rd of March. Viewed 6 April, https://www.europarl.europa.eu/news/en/press-room/20200313IPR74911/sassolipositive-measures-europe-united-in-face-of-common-covid-19-challenge

Ferrera, Maurizio \& Giuliani, Marco (eds., 2008), Governance e politiche nell'Unione europea. Studi e Ricerche. Il Mulino. Bologna.

Gstöhl, Sieglinde \& Phinnemore, David (2020), 'The future EU-UK partnership: a historical institutionalist perspective', Journal of European Integration, published online 7 September, https://doi.org/10.1080/07036337.2020.1818074

Habermas, Jürgen (2001a), The Postnational Constellation - Political Essays. MIT Press, February.

Habermas, Jürgen (2001b) Why Europe Needs a Constitution, New Left Review, SeptemberOctober. Viewed 2 November 2020, https://newleftreview.org/issues/II11/articles/jurgen-habermas-why-europe-needsa-constitution

Habermas, Jürgen et al. (2010), An Awareness of What is Missing: Faith and Reason in a Post-secular Age. Polity Press.

Irwin, Neil (2015), 'How Germany Prevailed in the Greek Bailout.' The New York Times, 29 July. Viewed 6 April 2020:

https://www.nytimes.com/2015/07/30/world/europe/how-germany-prevailed-inthe-greek-bailout.html

Jiménez Lobeira, Pablo Cristóbal (2010a), 'EU Analogical Identity - or the Ties That Link (without Binding).' Australia National University Centre for European Studies Briefing Paper Series 1, no. 2, September. Viewed 2 April 2020, https://politicsir.cass.anu.edu.au/centres/ces/research/publications/briefingpaper?page $=5$

Jiménez Lobeira, Pablo Cristóbal (2010b), 'Exploring an Analogical Citizenship for Europe' Open Citizenship No. 1, Issue 1, October: 28-49, viewed 29 April 2020, https://oc.citizensforeurope.org/ojs/exploring-an-analogical-citizenship-for-europe/

Jiménez Lobeira, Pablo Cristóbal (2010c), 'Normative Conceptions of European Identity - a Synthetic Approach.' Australian Journal of Professional and Applied Ethics Vol. 12, Numbers 1 \& 2 December: 159-70, viewed 5 May 2020, https://philarchive.org/rec/JIMNCO?all_versions=1

Jiménez Lobeira, Pablo Cristóbal (2011a), 'Liberal Democracy: Culture Free? The HabermasRatzinger Debate and Its Implications for Europe.' Australian \& New Zealand Journal of European Studies Volume 2, No 2 / Volume 3, No 1 May/June: 44-57 viewed 2 April 2020, https://cesaa.org.au/anzjes issue/volume-2-no-2-volume-3no-1/

Jiménez Lobeira, Pablo Cristóbal (2012), 'EU Citizenship and Political Identity: The Demos and Telos Problems.' European Law Journal 18, no. 4 July, pp. 504-517, https://doi.org/10.1111/j.1468-0386.2012.00612.x

Jiménez Lobeira, Pablo Cristóbal (2014a), 'Veils, Crucifixes and the Public Sphere: What Kind of Secularism? Rethinking Neutrality in a Post-secular Europe.' Journal of Intercultural Studies Vol. 35, Issue 4, June, https://doi.org/10.1080/07256868.2014.913009 
Jiménez Lobeira, Pablo Cristóbal (2014b), 'Is Europe still worth fighting for? Allegiance, identity and integration paradigms revisited', in Fiona Jenkins, Mark Nolan \& Kim Rubenstein (eds) Allegiance and Identity in a Globalised World, Cambridge University Press, Vol. 2 November, pp. 94 - 114, https://doi.org/10.1017/CBO9781139696654.008

Jiménez Lobeira, Pablo Cristóbal (2015), 'European Identity and Other Mysteries-Seeking Out the Hidden Source of Unity for a Troubled Polity.' Hermes Analógica n. 6. Viewed 2 April 2020, https://sites.google.com/site/hermesanalogica/no-6---2015

Kalampakou, Eleni (2019), 'Is There a Right to Choose a Religious Jurisdiction over the Civil Courts? The Application of Sharia Law in the Minority in Western Thrace, Greece', Religions 10(4), 260, https://doi.org/10.3390/rel10040260

Ładykowski, Pawel (2018), 'National Belonging' in Legal and Diplomatic Formulas: The Pole's Card as a Legacy of Poland's Colonial History'. Baltic Journal of European Studies, Vol. 8, Issue 2, December, https://doi.org/10.1515/bjes-2018-0017

Longo, E. (2019), 'The European Citizens' initiative: too much democracy for EU polity?', German Law Journal, Cambridge University Press, 20(2), 5 April, pp. 181-200, https://doi.org/10.1017/glj.2019.12

Macron, Emmanuel (2020a), 'La République en actes: discours du Président de la République sur le thème de la lutte contre les séparatismes.' Présidence de la République, Élysée, 2 October. Viewed 27 October 2020, https://www.elysee.fr/emmanuel-macron/2020/10/02/la-republique-en-actesdiscours-du-president-de-la-republique-sur-le-theme-de-la-lutte-contre-lesseparatismes

Macron, Emmanuel (2020b), 'Cérémonie d'hommage national à Samuel Paty à la Sorbonne.' Présidence de la République, Élysée, 21 October. Viewed 31 October 2020, https://www.elysee.fr/emmanuel-macron/2020/10/21/ceremonie-dhommagenational-a-samuel-paty-a-la-sorbonne

Miller, Fred D. (2018), 'Aristotle's Political Theory', The Stanford Encyclopedia of Philosophy (Winter Edition), Edward N. Zalta (ed.), Viewed 31 October 2020, https://plato.stanford.edu/archives/win2018/entries/aristotle-politics/

Nicolaïdis, Kalypso (2004), 'The new constitution as european “demoi-cracy”?', Critical Review of International Social and Political Philosophy, 7:1, 76-93, DOI: $10.1080 / 1369823042000235985$

Petrov, Roman (2018). 'EU common Values in the EU-Ukraine association agreement: anchor to democracy?' Baltic Journal of European Studies, Tallinn University of Technology (ISSN 2228-0588), Vol. 8, No. 1 (24), June, https://doi.org/10.1515/bjes2018-0004

Pew Research Centre (2015), Pew-Templeton Global Religious Futures project, 'The Future of World Religions: Population Growth Projections, 2010-2050', April. Viewed 4 April 2020, http://www.globalreligiousfutures.org/countries

Pew Research Centre (2017), 'Europe’s Growing Muslim Population', November. Viewed 9 December 2020, https://www.pewforum.org/2017/11/29/europes-growing-muslimpopulation/

Politico (2020a), 'EU leaders agree on $€ 1.82 \mathrm{~T}$ budget and coronavirus recovery package', 21 July 2020. Viewed 21 July 2020, https://www.politico.eu/article/eu-leaders-reachdeal-on-coronavirus-recovery-fund/ 
Politico (2020b), 'Overall No. 1, The Most Powerful Person in Europe: Angela Merkel, The Linchpin', Politico 28 Class of 2021, 7 December. Viewed 11 December 2020, https://www.politico.eu/list/politico-28-class-of-2021-ranking/angela-merkel/

Ratzinger, Joseph (2019), 'Western Culture: Today and Tomorrow - Addressing the Fundamental Issues', Ignatius Press.

Rettman, Andrew (2020), 'Nice attack: EU urges world leaders to stop hate speech', $E U$ Observer, Brussels, 31 October, 7:17. Viewed 31 October 2020, https://euobserver.com/justice/149917

Savarit-Lebrère, Aurore (2020), 'Hommage national à Samuel Paty: «Nous te saluons, camarade»', Liberation, 21 October, 21:08. Viewed 28 October 2020, https://www.liberation.fr/france/2020/10/21/je-suis-maman-je-suis-samuel-toutmon-amour-monsieur-le-professeur 1803108

Schmidt, Vivien Ann (2015), 'The Impact of European Integration on National Democracies: Democracy at Increasing Risk in the Eurozone Crisis." In The Search for Europe. Contrasting Approaches. Madrid: BBVA, pp. 216-237. Viewed 16 July 2020, https://www.bbvaopenmind.com/en/books/the-search-for-europe-contraisingapproaches/

Shaw, Jo and Wiener, Antje (2000), 'The Paradox of the "European Polity", in M. Green Cowles and M. Smith (eds), The State of the European Union: Risks, Resistance and Revival, Oxford, Oxford University Press, pp. 64-89, https://doi:10.1093/0198297572.001.0001

Turnbull-Dugarte, Stuart J. (2020) 'A new hope for europhiles? The 2017 German federal elections and the revenge of the pro-European mainstream', Journal of European Integration, https://10.1080/07036337.2020.1826943

Vaaks, Katri (2013), 'The European Union in the Estonian Public Discourse.' Baltic Journal of European Studies, Vol. 3, Issue 2, October, https://doi.org/10.2478/bjes-2013-0013

Varga, Máté (2020), 'As Poles and Hungarians, we urge the EU to stand firm on the rule of law', The Guardian, 10 December. Viewed 11 December 2020, https://www.theguardian.com/world/commentisfree/2020/dec/10/poleshungarians-urge-eu-stand-firm-rule-law-orban-morawicki

Verwey, M., Langedijk, S. \& Kuenzel, R. (2020). 'Next Generation EU: A recovery plan for Europe', VoxEU.org - Centre for Economic Policy Research, 9 June. Viewed 7 July 2020: https://voxeu.org/article/next-generation-eu-recovery-plan-europe

Voters Without Borders (2020), 'Voters Without Borders -full political rights for EU citizens. Help us campaign for a better European Union!', viewed 21 July 2020, https://voterswithoutborders.eu/

Wallace, Helen (2000), 'EU Enlargement: A Neglected Subject', in M. Green Cowles and M. Smith (eds), The State of the European Union: Risks, Resistance and Revival, Oxford, Oxford University Press, pp. 149-163, https://doi:10.1093/0198297572.001.0001

Weiler, Joseph (1991), 'The Transformation of Europe', 100 Yale Law Journal. Viewed 3 November 2020, https://digitalcommons.law.yale.edu/ylj/vol100/iss8/5

Weiler, Joseph (1998), 'To be a European Citizen - "Eros and Civilization”, Working Paper Series in European Studies, Special Edition, Spring. European Studies Program, International Institute, University of Wisconsin--Madison. Viewed 2 November 2020, http://aei.pitt.edu/8990/1/weiler.pdf 
Weiler, Joseph (1999), 'The constitution of Europe: 'Do the new clothes have an emperor?' and other essays on European integration, Cambridge University Press.

Weiler, Joseph (2005), 'On the Power of the World: Europe's Constitutional Iconography', I.CON Volume 3, Numbers 2 \& 3, Special Issue, May, pp. 173-190. Oxford University Press and New York University School of Law. Viewed 3 November 2020, https://academic.oup.com/icon/article-pdf/3/2-3/173/1715361/moio15.pdf

Zalan, Eszter (2020), 'Michel lays out compromise budget plan for summit', EU Observer, 10 July, viewed 12 July 2020, https://euobserver.com/economic/148917 